\title{
Inhibition of DNA Methylation at the MLH1 Promoter Region Using Pyrrole-Imidazole Polyamide
}

\author{
Ken-ichi Shinohara, ${ }^{\dagger, \dagger}$ Natsumi Yoda, ${ }^{\dagger}$ Kiyoko Takane, ${ }^{\dagger}$ Takayoshi Watanabe, ${ }^{\S}$ Masaki Fukuyo, ${ }^{\dagger}$

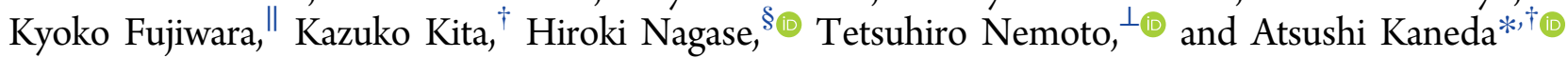

${ }^{\dagger}$ Department of Molecular Oncology, Graduate School of Medicine and ${ }^{\perp}$ Department of Pharmaceutical Chemistry, Graduate School of Pharmaceutical Sciences, Chiba University, 1-8-1 Inohana, Chuo-ku, Chiba 260-8670, Japan

${ }^{\ddagger}$ Institute for Global and Prominent Research, Chiba University, 1-33 Yayoi-cho, Inage-ku, Chiba 263-8522, Japan

${ }^{\S}$ Laboratory of Cancer Genetics, Chiba Cancer Center Research Institute, 666-2 Nitona, Chuo-ku, Chiba 260-8717, Japan

"Innovative Therapy Research Group, Nihon University Research Institute of Medical Science, Nihon University School of Medicine, 30-1 Ooyaguchi-kami, Itabashi-ku, Tokyo 173-8610, Japan

\section{Supporting Information}

ABSTRACT: Aberrant DNA methylation causes major epigenetic changes and has been implicated in cancer following the inactivation of tumor suppressor genes by hypermethylation of promoter $\mathrm{CpG}$ islands. Although methylated DNA regions can be randomly demethylated by 5-azacytidine and 5-aza-2'-deoxycytidine, site-specific inhibition of DNA methylation, for example, in the promoter region of a specific gene, has yet to be technically achieved. Hairpin pyrrole (Py)imidazole $(\mathrm{Im})$ polyamides are small molecules that can be designed to recognize and bind to particular DNA sequences. In this study, we synthesized the hairpin polyamide MLH1_-

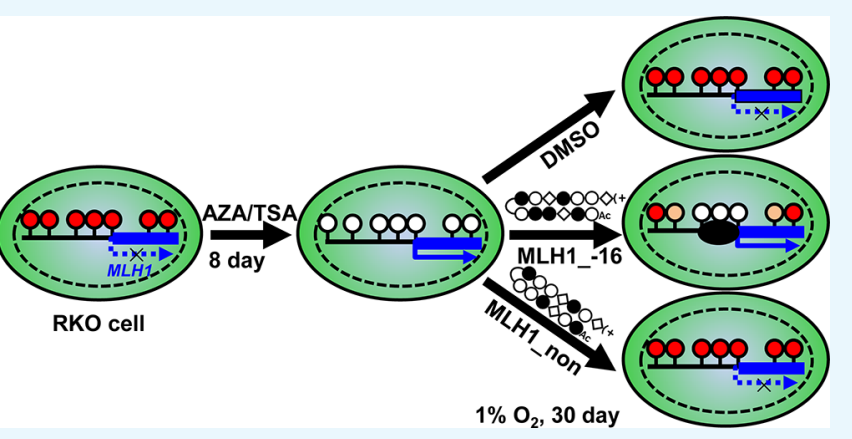
16 (Py-Im- $\beta$-Im-Im-Py- $\gamma$-Im-Py- $\beta$-Im-Py-Py) to target a $\overline{\mathrm{CpG}}$ site $16 \mathrm{bp}$ upstream of the transcription start site of the human MLH1 gene. MLH1 is known to be frequently silenced by promoter hypermethylation, causing microsatellite instability and a hypermutation phenotype in cancer. We show that MLH1_16 binds to the target site and that CpG methylation around the binding site is selectively inhibited in vitro. MLH1_non, which does not have a recognition site in the $M L H 1$ promoter, neither binds to the sequence nor inhibits DNA methylation in the region. When $\mathrm{MLH1}$ _ 16 was used to treat RKO human colorectal cancer cells in a remethylating system involving the $M L H 1$ promoter under hypoxic conditions $\left(1 \% \mathrm{O}_{2}\right)$, methylation of the $M L H 1$ promoter was inhibited in the region surrounding the compound binding site. Silencing of the $M L H 1$ expression was also inhibited. Promoter methylation and silencing of $M L H 1$ were not inhibited when MLH1_non was added. These results indicate that Py-Im polyamides can act as sequence-specific antagonists of $\mathrm{CpG}$ methylation in living cells.

\section{INTRODUCTION}

DNA methylation involves a modification to the cytosine at the 5 position, generally occurring within a $\mathrm{CpG}$ dinucleotide in adult somatic cells. ${ }^{1}$ Unmethylated CpGs are often grouped in clusters, called $\mathrm{CpG}$ islands, in the $5^{\prime}$ regulatory regions of genes. In many disease processes including cancer, $\mathrm{CpG}$ islands in gene promoters acquire abnormal hypermethylation that is inherited by daughter cells via DNA methyltransferase 1 (DNMT1) during cell division. Aberrant DNA methylation of gene promoter regions is therefore one of the most significant epigenetic alterations, resulting in the silencing of tumor suppressor genes. ${ }^{2,3}$ A subgroup of colorectal cancers and other malignant tumors possess the so-called $\mathrm{CpG}$ island methylator phenotype (CIMP), in which cells exhibit aberrant promoter methylation in many genes. ${ }^{4-6}$ The mismatch repair gene MLH1 is known to be hypermethylated in the late stages of CIMP-positive colorectal adenoma, leading to the disruption of mismatch repair and thus development of colorectal cancer with microsatellite instability (MSI) and a hypermutation phenotype. $^{7-9}$

The small molecule 5-aza-2'-deoxycytidine (AZA) is known to be a hypomethylating agent. ${ }^{10,11}$ It destabilizes DNMT1, leading to increased hypomethylated DNA. This destabilization is caused by the incorporation of AZA into DNA instead of deoxycytidine, resulting in covalent methyltransferase-AZA adducts. ${ }^{12}$ Although azacytosine-guanine dinucleotides are recognized by DNMT1 as a natural substrate, the reaction is blocked by AZA, in which carbon-5 is substituted by nitrogen. AZA has been approved by the U.S. Food and Drug Administration for inducing genome-wide hypomethylation in

Received: September 7, 2016

Accepted: November 28, 2016

Published: December 9, 2016 
the treatment of myelodysplastic syndrome, a class of conditions where certain blood cells are dysfunctional and of acute myeloid leukemia. ${ }^{13-15}$ In addition to AZA, DNAbinding molecules such as echinomycin have also been reported to disrupt $\mathrm{CpG}$ methylation in vitro, ${ }^{16}$ though their clinical application has been limited because of the cytotoxicity of these molecules. Moreover, none of these molecules are able to demethylate CpGs in a site- or region-specific manner because they do not selectively recognize the DNA sequences surrounding the $\mathrm{CpG}$ dinucleotides. A technique for DNA hypomethylation that selectively targets the aberrantly hypermethylated promoter $\mathrm{CpG}$ islands of critical tumor suppressor genes, therefore, has not been developed yet.

Pyrrole (Py)-imidazole (Im) polyamides (PIPs) are a class of small molecules that bind to the minor groove of DNA. ${ }^{17-21}$ Intramolecular stacking of the face-to-face heterocycles gives PIPs a hairpin structure. An antiparallel pairing of Im opposite Py $(\mathrm{Im} / \mathrm{Py})$ preferentially binds to a $\mathrm{G} / \mathrm{C}$ base pair, whereas a Py/Py pair recognizes $\mathrm{A} / \mathrm{T}$ or $\mathrm{T} / \mathrm{A}$ base pair. ${ }^{17,22,23} \beta$-Alanine acts as an aliphatic substitute for a Py ring to match the curvature of the minor groove surfaces at longer binding sites. $^{24,25}$ It has been shown that the energetic preferences of these programmable molecules are comparable to those of natural transcription factors and other DNA binding proteins. $^{21,26-29}$

Dervan and colleagues have recently reported an eight-ring hairpin PIP targeting the sequence 5'-CGCG-3' as a model for CpG methylation inhibition in vitro. ${ }^{30}$ This model suggested that PIP recognizing $\mathrm{CpG}$ sites could provide a molecular basis for the design of sequence-selective antagonists of $\mathrm{CpG}$ methylation. MLH1 is one of the well-known genes that are often hypermethylated in cancer. ${ }^{7-9}$ MLH1 protein works as a machinery of DNA-mismatch repair; hence, its silencing via DNA hypermethylation causes genomic instability resulting in tumor genesis. ${ }^{31,32}$ Therefore, we designed a longer hairpin PIP comprising ten rings and two $\beta$-alanines that recognizes $8 \mathrm{bp}$ in the promoter of $M L H 1$ to target it selectively. In this study, we sought to determine whether this PIP is able to prevent genesilencing by inhibiting DNA methylation in a site- or regionselective manner in living cells. We here demonstrate the ability of the MLH1-selective PIP to inhibit DNA methylation around the recognition site and to maintain the expression of $M L H 1$ in colorectal cancer cells.

\section{RESULTS AND DISCUSSION}

2.1. Construction of PIPs and Binding to MLH1 Promoter Region. We designed two hairpin PIPs (Figure 1A), one that recognizes a sequence in the $M L H 1$ promoter (MLH1_-16) and one that does not (MLH1_non). The sequence $5^{\prime}$-AGCCGCTT- $3^{\prime}$ in the promoter region of $M L H 1$ is the target DNA sequence for $\mathrm{MLH} 1 \_-16$ including the CpG site, which is the upstream 8-bp region nearest from the transcription start site (TSS). MLH1_non contains the same ring number as MLH1 -16 and has the potential to recognize the sequence $5^{\prime}-\mathrm{WGW} \overline{\mathrm{C} C W G C W}-3^{\prime}(\mathrm{W}=\mathrm{A}$ or $\mathrm{T})$ that does not exist within $\pm 1 \mathrm{~kb}$ of the MLH1 TSS (Figure 1B). To determine the binding affinities and specificities of the two PIPs to the MLH1 target DNA sequence, gel mobility shift assays were conducted. These clearly indicated that MLH1_-16 bound to the appropriate 15-bp double-stranded $\overline{D N A}$ (dsDNA) sequence in the upstream region of $M L H 1$. By contrast, MLH1_non did not bind to this DNA region (Figure 1C).
A

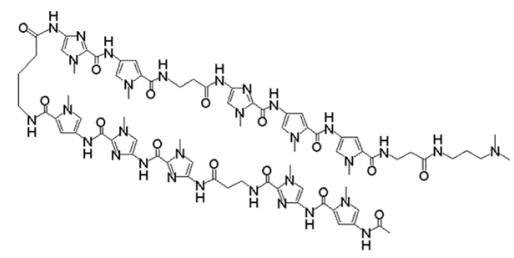

MLH1_-16: Ac-Py-Im- $\beta-\operatorname{Im}-\mathrm{Im}-\mathrm{Py}-\gamma-\mathrm{Im}-\mathrm{Py}-\beta-\mathrm{Im}-\mathrm{Py}-\mathrm{Py}-\beta-\mathrm{Dp}$

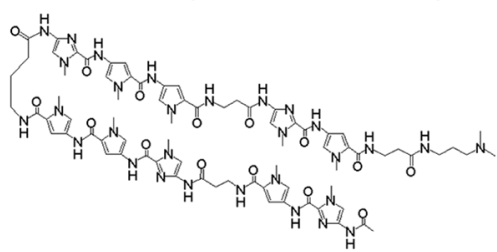

MLH1_non: AC-Im-Py- $\beta-I m-P y-P y-\gamma-I m-P y-P y-\beta-I m-P y-\beta-D p$

B

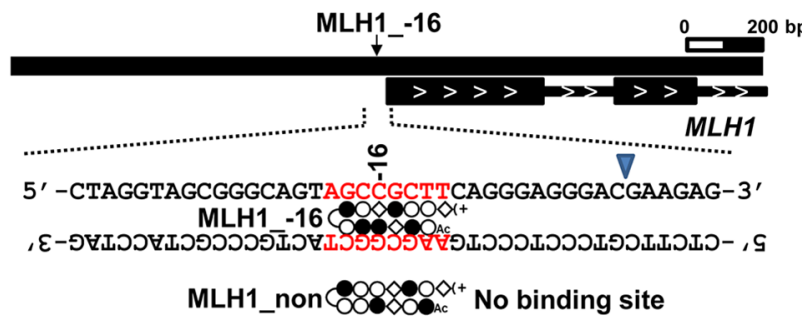

C

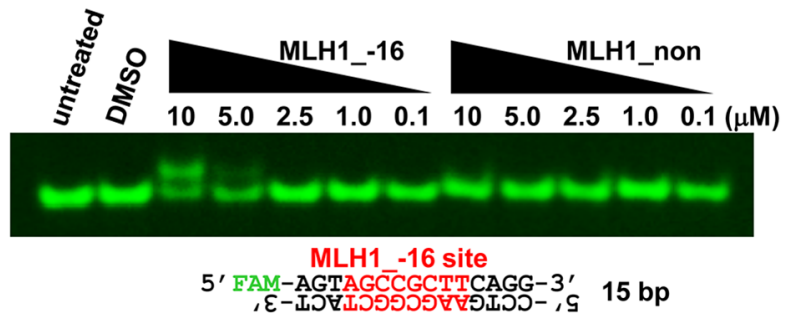

Figure 1. Chemical properties of hairpin PIPs targeting the MLH1 promoter. (A) Chemical structure of MLH1_-16 and MLH1_non. (B) Schematic diagram showing the binding site of MLH1 $-1 \overline{6}$ near the TSS (arrowhead) of the human MLH1 promoter. The expected binding site is indicated with an arrow and in red. There is no binding site of MLH1_non within $1 \mathrm{~kb}$ from the TSS of MLH1. Ball-and-stick models of the polyamides are shown between the two DNA strands. Closed and open circles represent $\mathrm{Im}$ and Py rings, respectively, diamonds represent $\beta$-alanine, and curved lines represent $\gamma$-aminobutyric acid. (C) Investigation of binding affinities of MLH1_-16 and MLH1_non to target DNA in vitro by EMSA on a $20 \%$ polyacrylamide gel. Lane 1, double-stranded untreated DNA; lane 2, DNA treated with 5\% DMSO (control); lanes 3-7, DNA treated with various concentrations of MLH1 -16; and lanes 8-12, DNA treated with various concentrations of MLH1_non. Mobility of 5'-FAMlabeled DNA corresponding to the MLH1_-16 binding site (red letters) was delayed in the presence of $\mathrm{MLH1}_{-}^{-}-16(5$ or $10 \mu \mathrm{M})$, but not in the presence of MLH1_non.

2.2. Inhibition of in Vitro DNA Methylation by PIP. A plasmid containing $1.3 \mathrm{~kb}$ of DNA sequence from the $5^{\prime}$ region of $M L H 1$ ( -780 to +483 ) (Figure $2 \mathrm{~A}$ ) was subjected to in vitro methylation by SssI methylase (M. SssI) in the presence or absence of PIPs. Methylation levels at $\mathrm{CpG}$ sites at positions $-70,-63,-27,-16,-1,+157$, and +172 were quantitatively estimated using pyrosequencing (Figure 2B). This confirmed that all CpGs analyzed were fully methylated in the absence of PIPs. In the presence of $5 \mu \mathrm{M}$ or more MLH1_-16, however, the methylation levels were significantly reduced at the targeted position $(-16)$ and at nearby positions -27 and -1 . 


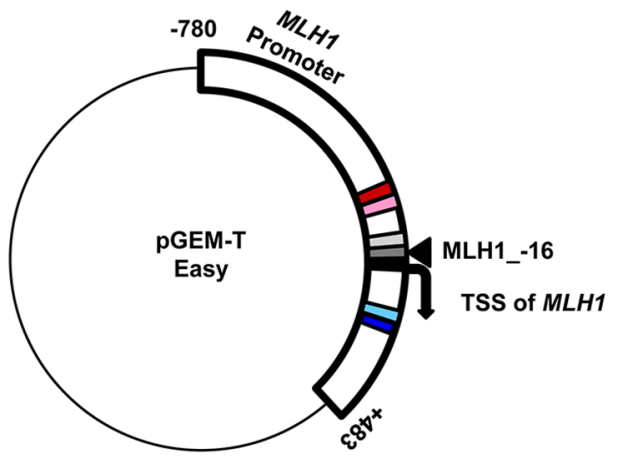

B

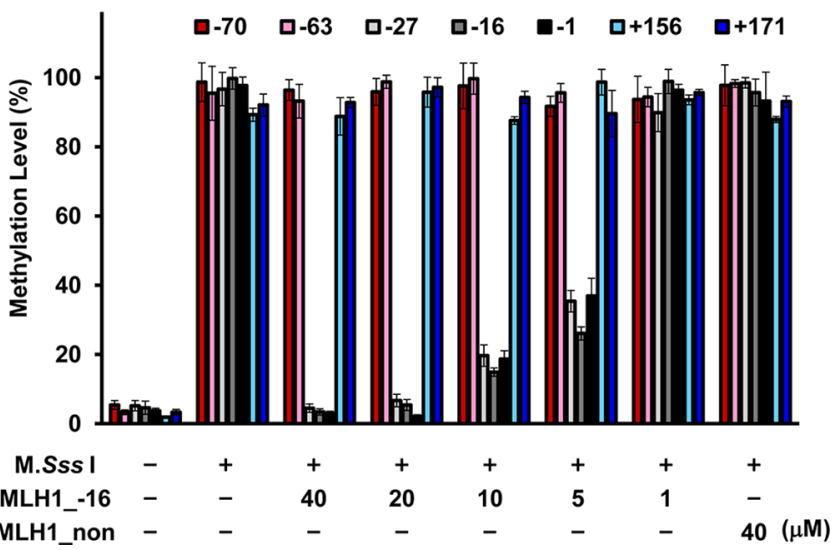

Figure 2. Site-specific inhibition of DNA methylation by MLH1_-16 in vitro. (A) Schematic presentation of plasmid DNA including the promoter region of $M L H 1(-780$ to +483 , white bar) that was used in this assay. MLH1_-16 binding site is indicated with a black triangle. Eight CpG sites at positions $-70,-63,-27,-16,-1,+156$, and +171 are shown as red, pink, light gray, gray, black, light blue, and blue bars, respectively. (B) Pyrosequencing analysis of DNA methylation levels in the $M L H 1$ promoter following DNA methylation and treatment with MLH1_-16 or MLH1_non in vitro. Colored bars match those in (A). Data represent the mean of three independent replicates $\pm S D$. DNA methylation was inhibited at positions $-27,-16$, and -1 in the presence of MLH1_-16.

Methylation at positions further upstream and downstream was not inhibited. By contrast, MLH1_non did not inhibit in vitro methylation at any position, even at a concentration of $40 \mu \mathrm{M}$. This demonstrates that selective binding of MLH1_-16 to a specific DNA sequence causes selective inhibition of DNA methylation in vitro. The half-maximal inhibitory concentration (IC50) of MLH1_-16 was estimated as $3.2 \mu \mathrm{M}$.

2.3. Localization of PIP in the Nucleus. The next question was whether MLH1_-16 can inhibit MLH1 methylation in cellulo, thereby inhibiting $M L H 1$ silencing. To first confirm that the PIPs were incorporated into cells and localized to the nucleus, rectal carcinoma ( $\mathrm{RKO}$ ) cells were incubated with FAM-labeled MLH1_-16 (Figure 3A) and then fixed with formaldehyde. Strong green fluorescent signals were detected in the nuclei of these cells (Figure 3B). Nuclear localization of MLH1_non had already been confirmed in a previous study, ${ }^{26}$ and its uptake into RKO cells was also demonstrated (Figure S1). Thus, we confirmed that both PIPs can be easily incorporated into RKO cells and rapidly localized to the nuclei. Surface plasmon resonance (SPR) analysis was conducted to evaluate the binding affinity of MLH1_-16 to the target DNA 5'-AGCCGCTT-3' sequence (Figure S2).
A

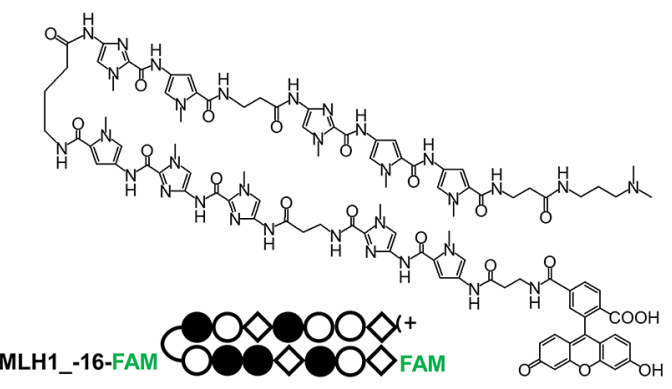

B
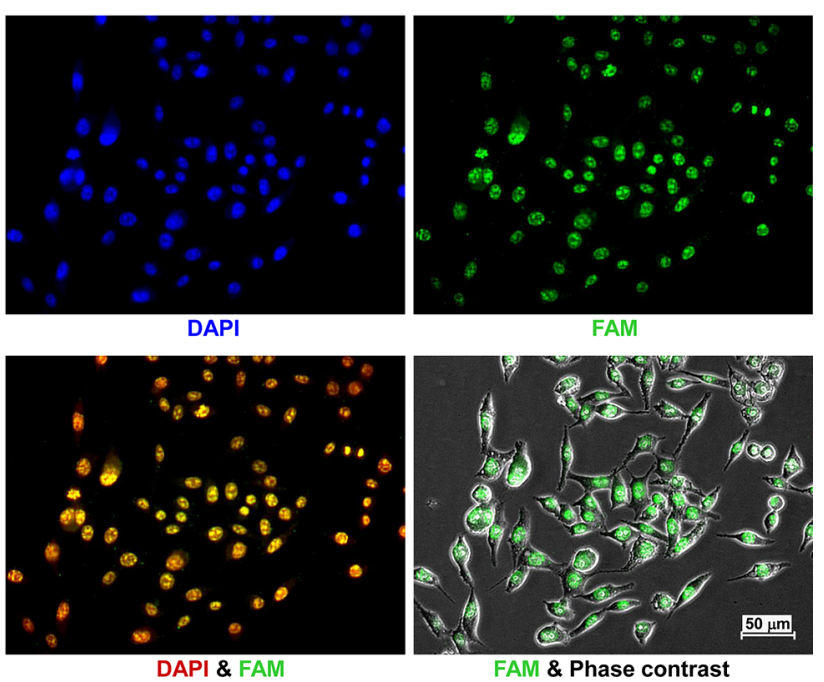

Figure 3. Distribution of FAM-labeled MLH1_-16 in RKO cells after 1 day of incubation. (A) Chemical structure of the FAM-labeled MLH1_-16. (B) Cells were visualized using fluorescence microscopy following nuclear staining with DAPI (blue or red). MLH1_-16 was localized in the nuclei of RKO cells after 1 day. MLH1_non was also confirmed to be localized in the nuclei (Figure S1).

Dissociation equilibrium constant $\left(K_{\mathrm{D}}=k_{\mathrm{d}} / k_{\mathrm{a}}\right.$, in which $k_{\mathrm{d}}$ and $k_{\mathrm{a}}$ are the dissociation and association rate constants, respectively) was estimated to be $2.7 \times 10^{-8} \mathrm{M}\left[k_{\mathrm{d}}=1.06 \times\right.$ $10^{-3}(1 / \mathrm{s})$ and $\left.k_{\mathrm{a}}=3.96 \times 10^{4}(1 / \mathrm{M} \cdot \mathrm{s})\right]$ using SPR analysis.

2.4. Inhibition of DNA Methylation in Living Cells by PIP. Before PIPs were given to living cells, optimization of the PIP concentration was performed using WST-8 assay. MLH1_-16 and MLH1_non were found to have no cytotoxic effects at concentrations of up to $10 \mu \mathrm{M}$ for $72 \mathrm{~h}$ (Figure S3). However, crystallization of MLH1_-16 and MLH1_non was observed at $10 \mu \mathrm{M}$. We therefore chose a concentration of 5.0 $\mu \mathrm{M}$ for the 30-day treatment in this study.

Because it is known that $\mathrm{CpG}$ sites of the $\mathrm{MLH} 1$ promoter in RKO cells are highly methylated, ${ }^{33}$ we examined whether the MLH1_-16 treatment could reduce the methylation levels in a site-specific manner. RKO cells were first treated with MLH1_-16 or MLH1_non at a concentration of $5.0 \mu \mathrm{M}$ for 30 days, and the $M L H \overline{1}$ methylation levels on $-27,-16$, and $-1 \mathrm{CpG}$ sites were analyzed. There was no significant reduction of DNA methylation by simple treatment of MLH1_-16 (Figure 4), hence, we applied AZA-hypoxia treatment on RKO cells, which was reported previously, ${ }^{33}$ to induce DNA methylation in the $M L H 1$ promoter region.

2.5. DNA Methylation at the MLH1 Promoter Region under Hypoxia. To assess the effect of the PIPs on DNA methylation in living cells, we first sought to confirm that 


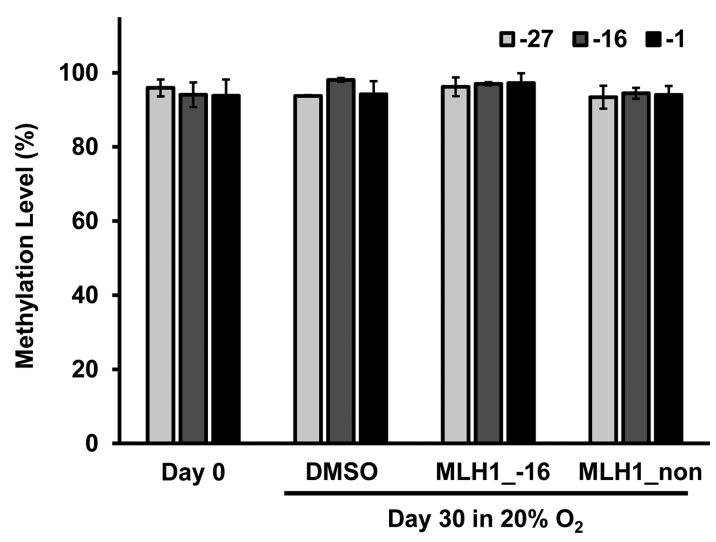

Figure 4. DNA methylation levels of $M L H 1$ in RKO cells treated with MLH1_-16 or MLH1_non for 30 days. RKO cells were treated with $0.1 \% \overline{D M S O}$ (control), $5 \mu \mathrm{M}$ MLH1 16 , or $5 \mu \mathrm{M}$ MLH1 non under normal conditions $\left(20 \% \mathrm{O}_{2}\right)$. Data represent the mean of three independent replicates \pm SD. No significant reduction of DNA methylation at positions $-27,-16$, and -1 was observed compared with untreated control (day 0 ).

methylation could be induced in RKO cells by hypoxia after demethylation with AZA treatment, as previously reported. ${ }^{33}$ First, RKO cells underwent AZA treatment to demethylate the $M L H 1$ promoter region (Figure 5). Without AZA treatment, the methylation levels at positions $-27,-16$, and -1 in the MLH1 promoter region of RKO cells were 91.1, 93.4, and 92.2\% (Figure 5A), respectively, whereas those in RKO cells treated with AZA were reduced to 44.1, 42.1, and 41.8\% [P= 0.0004 vs dimethyl sulfoxide (DMSO) control], respectively. When RKO cells were treated with the histone deacetylase inhibitor (trichostatin A; TSA) in combination with AZA to synergistically enhance gene activation by acetylating histones and demethylating DNA, ${ }^{34,35}$ the methylation levels were also reduced to similar levels: $43.5,48.0$, and $47.9 \%(P=0.0002$ vs DMSO control), respectively. The MLH1 expression was completely silenced in untreated RKO cells (Figure 5B), but this silencing was somewhat or markedly inhibited by treatment with AZA or AZA + TSA, respectively.

Next, RKO cells treated with AZA for 8 days were subsequently cultured under hypoxic conditions $\left(1 \% \mathrm{O}_{2}\right)$ to inactivate $M L H 1$, as previously reported. ${ }^{33}$ As shown in Figure $6 \mathrm{~A}$, the DNA methylation levels at positions $-27,-16$, and -1 had significantly increased to $75.8,71.8$, and $72.3 \%$, respectively, by day $20(\mathrm{H} 20 ; P=0.002$ vs $\mathrm{H} 0)$ and had increased to $88.5,91.8$, and $90.4 \%$, respectively, by $\mathrm{H} 30$ ( $P=5$ $\times 10^{-6}$ vs $\mathrm{H0}$ ). Consequently, the $\mathrm{MLH1}$ expression was completely silenced at $\mathrm{H} 20$ and $\mathrm{H} 30$ (Figure 6B). Similarly, RKO cells treated with both AZA and TSA for 8 days were cultured under hypoxic conditions (Figure 6A). The DNA methylation levels at positions $-27,-16$, and -1 increased significantly to $72.6,74.1$, and $73.5 \%$, respectively, at $\mathrm{H} 20$ ( $P=$ 0.0003 vs $\mathrm{H0}$ ) and to $89.0,94.3$, and $87.2 \%$, respectively, at $\mathrm{H} 30$ ( $P=0.0004$ vs $\mathrm{H} 0)$. MLH1 was markedly expressed at H0, somewhat repressed at $\mathrm{H} 20$, and completely silenced at $\mathrm{H} 30$ (Figure 6B). We therefore determined that treatment with AZA + TSA should be a better condition for subsequent analyses.

2.6. Inhibition of DNA Methylation in Living Cells by PIP in Hypoxia after AZA + TSA Treatment. RKO cells underwent pretreatment with AZA + TSA, producing similar results to those obtained in the DNA methylation analysis above (Figure 7A). Under hypoxic conditions with no PIP
A
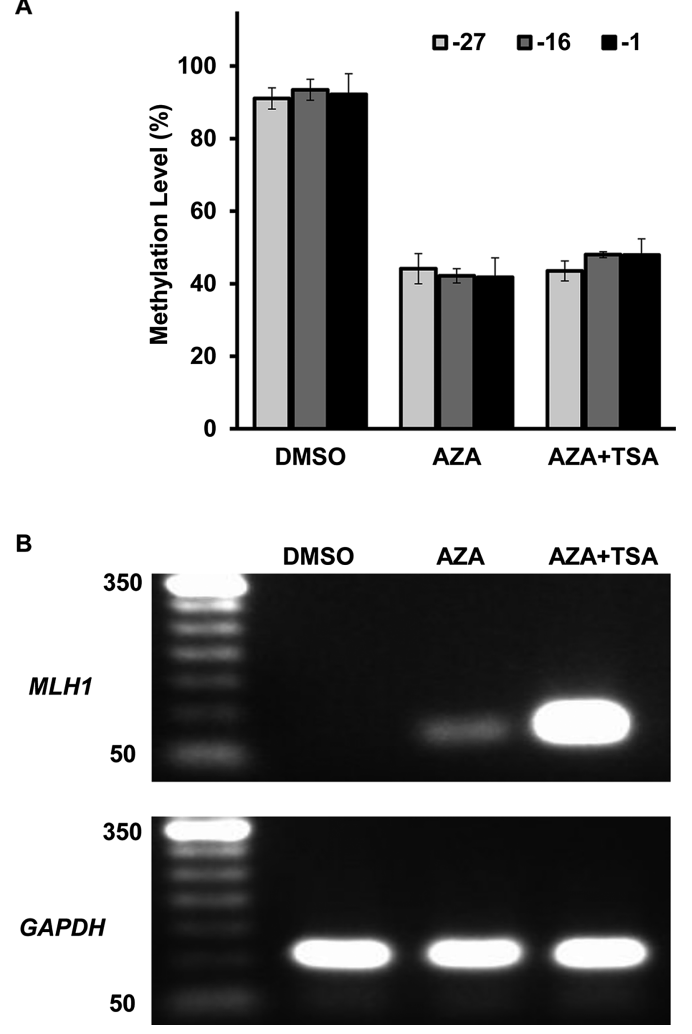

Figure 5. Decreased DNA methylation and increased MLH1 mRNA expression induced by AZA or AZA + TSA treatment of RKO cells. (A) DNA methylation levels in the MLH1 promoter of RKO cells treated with DMSO (control), AZA, or AZA + TSA. Data represent the mean of three independent replicates $\pm S D$. The methylation level in the MLH1 promoter was decreased by AZA or AZA + TSA treatment. (B) RT-PCR analysis of the $M L H 1$ expression in RKO cells treated with DMSO (control), AZA, or AZA + TSA. GAPDH was used as an internal control. MLH1 was re-expressed somewhat or markedly by treatment with AZA or AZA + TSA, respectively.

treatment, the DNA methylation levels at positions $-27,-16$, and -1 were $71.6,72.3$, and $70.4 \%$, respectively, at $\mathrm{H} 20$ and 89.4, 95.1, and $86.0 \%$, respectively, at $\mathrm{H} 30$. When treated with hypoxia and 5.0 $\mu \mathrm{M}$ MLH1_-16, however, the DNA methylation levels at $-27,-1 \overline{6}$, and -1 were significantly reduced to 58.5, 55.4, and 56.9\%, respectively, at $\mathrm{H} 20$ ( $P=$ 0.0005 vs DMSO control) and 64.0, 68.6, and $70.5 \%$, respectively, at $\mathrm{H} 30$ ( $P=0.003$ vs DMSO control). In the presence of $5.0 \mu \mathrm{M}$ MLH1_non, however, DNA methylation at $-27,-16$, and -1 was not inhibited, leading to methylation levels of 78.4, 72.3, and 74.4\%, respectively, at $\mathrm{H} 20$ ( $P=0.2$ vs DMSO control) and 92.2, 96.0, and 93.1\%, respectively, at $\mathrm{H} 30$ ( $P=0.3$ vs DMSO control).

DNA methylation levels at $\mathrm{CpG}$ sites further upstream and downstream from the MLH1_-16 binding sites $(-70,-63$, +157 , and +172 from TSS) were also analyzed. Similar to DNA methylation levels at positions $-27,-16$, and -1 , methylation was elevated at all sites under hypoxic conditions in a timedependent manner. In DMSO-treated (control) cells, the DNA methylation levels at $-70,-63,+157$, and +172 increased to $68.4,70.6,72.0$, and $80.2 \%$, respectively, at $\mathrm{H} 20$ and 79.3, 81.5, 89.7 , and $86.5 \%$, respectively, at $\mathrm{H} 30$. In MLH1_-16-treated cells, the methylation levels were somewhat reduced to 63.4, $60.4,66.0$, and $68.3 \%$, respectively, at $\mathrm{H} 20(P=0.04$ vs DMSO control) and 77.1, 75.8, 76.4, and $77.9 \%$, respectively, at $\mathrm{H} 30$ 
A

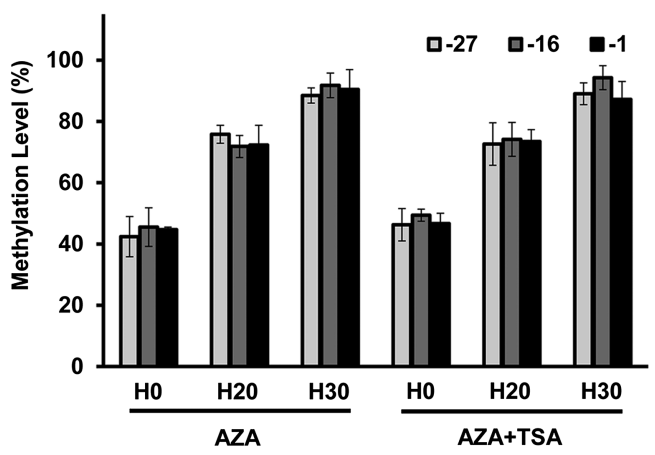

B

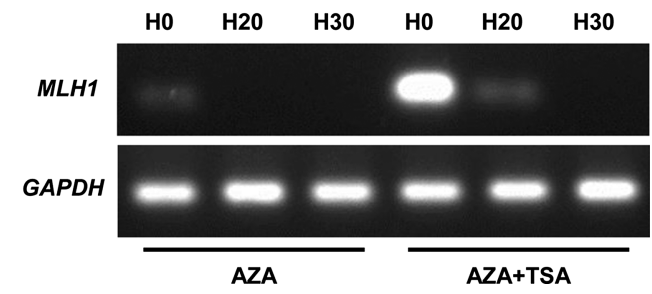

Figure 6. Increased DNA methylation and decreased $M L H 1$ mRNA expression in RKO cells incubated under hypoxia. (A) DNA methylation levels in the $M L H 1$ promoter of RKO cells treated with AZA or AZA + TSA and then incubated under hypoxic conditions ( $1 \%$ $\mathrm{O}_{2}$ ) for 0,20 , or 30 days (H0, H20, H30, respectively). Data represent the mean of three independent replicates $\pm \mathrm{SD}$. The methylation level of the $M L H 1$ promoter was increased under hypoxic conditions. (B) RT-PCR analysis of the $M L H 1$ expression in RKO cells treated with AZA or AZA + TSA and incubated under hypoxic conditions for 0,20 , or 30 days. GAPDH was used as an internal control. $M L H$ expression was silenced under hypoxic conditions.

( $P=0.047$ vs DMSO control). Inhibition of methylation was not observed, however, in MLH1_non-treated cells, with levels of $69.2,70.7,79.2$, and $73.7 \%$, respectively, at $\mathrm{H} 20$ ( $P=0.8$ vs DMSO control) and 84.2, 86.6, 92.9, and 89.0\%, respectively, at $\mathrm{H} 30$ ( $P=0.2$ vs DMSO control). Thus, DNA methylation at these $\mathrm{CpG}$ sites was slightly, but significantly, inhibited in the presence of MLH1_-16. Overall, the methylation levels of these seven $\mathrm{CpG}$ sites in MLH1_-16-treated cells were significantly inhibited compared with those of DMSO $(P=$ 0.0002 at $\mathrm{H} 20$ and 0.0002 at $\mathrm{H} 30)$ or those of MLH1_non ( $P$ $=0.00006$ at $\mathrm{H} 20$ and 0.000007 at $\mathrm{H} 30$ ), whereas there was no significant change between those of DMSO and MLH1_non ( $P$ $=0.2$ at $\mathrm{H} 20$ and 0.08 at $\mathrm{H} 30)$.

MLH1 was markedly expressed following AZA + TSA treatment and was silenced when treated with DMSO (control) or MLH1_non. In the presence of $5.0 \mu \mathrm{M}$ MLH1_-16, however, $\bar{M} L H 1$ was expressed, even at $\mathrm{H} 30$ (Figure $7 \mathrm{~B}$ ).

Additionally, DNA methylation at more distant CpG sites ( -589 and -579 from TSS) was assessed. There was no significant difference in the DNA methylation levels among the control, MLH1_-16-treated, and MLH1_non-treated cells (Figure S4). Similar to RKO cells pretreated with AZA + TSA, as above, the methylation levels at $-27,-16$, and -1 in RKO cells pretreated with AZA alone and then treated with MLH1_-16 were also significantly reduced compared with those in controls at both $\mathrm{H} 20$ and $\mathrm{H} 30$ (Figure S5A). However, the $M L H 1$ expression was completely silenced at $\mathrm{H} 20$ and $\mathrm{H} 30$ in all AZA-pretreated RKO cells (DMSO control, MLH1_-16, and MLH1_non; Figure S5B) presumably because of the low
A

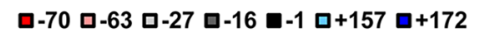
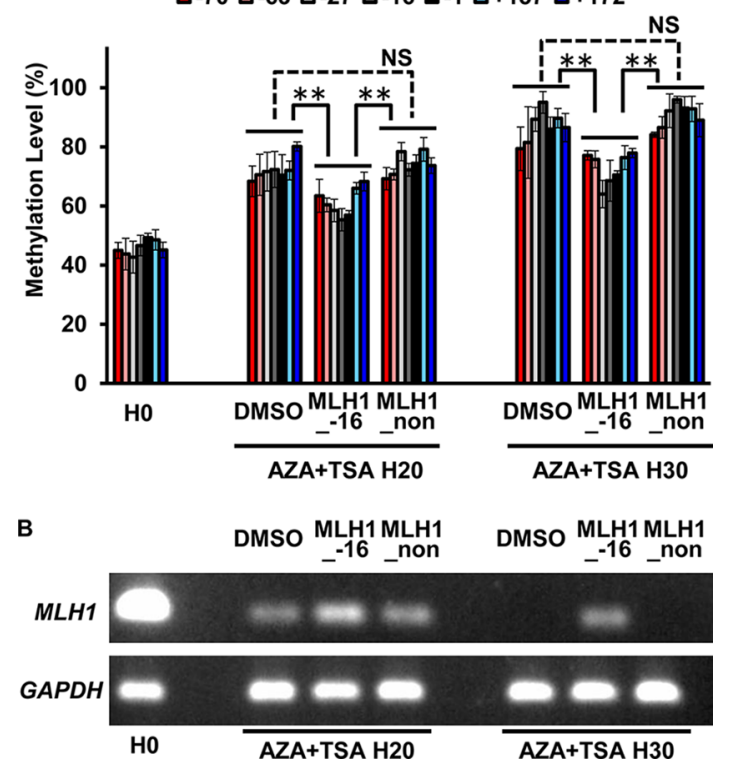

Figure 7. Selective inhibition of DNA methylation and MLH1 silencing by MLH1_-16 in RKO cells incubated under hypoxia. (A) DNA methylation levels in the $M L H 1$ promoter of RKO cells treated with AZA + TSA and then incubated under hypoxic conditions ( $1 \%$ $\mathrm{O}_{2}$ ) with DMSO (control), $5 \mu \mathrm{M}$ MLH1_-16, or $5 \mu \mathrm{M}$ MLH1_non. Data represent the mean of three independent replicates \pm SD. ${ }^{* *} P<$ 0.01 , N.S. not significant $(P>0.05)$. Increase of DNA methylation at positions $-70,-63,-27,-16,-1,+156$, and +171 was inhibited in the presence of MLH1_-16, but not in the presence of MLH1_non. (B) RT-PCR analysis of the MLH1 expression in RKO cells treated with AZA + TSA and then incubated under hypoxia with DMSO (control), MLH1_-16, or MLH1_non. GAPDH was used as an internal control. Silencing of $M L H \overline{1}$ was inhibited in the presence of MLH1_-16.

basal expression level of $M L H 1$ at $\mathrm{HO}$ in AZA-pretreated RKO cells.

2.7. PIP-Mediated Targeted Inhibition of DNA Methylation. The above experiments demonstrate that PIPs can induce region-selective inhibition of DNA methylation in living cells. MLH1_-16, which was designed to bind to the CpG site nearest to the TSS of the MLH1 gene, selectively inhibited DNA remethylation of the target $\mathrm{CpG}$ site and the surrounding region in RKO cells. This selective inhibition resulted in inhibition of re-silencing of the $M L H 1$ gene expression.

PIPs are molecules that selectively recognize DNA sequences. $^{20,21}$ The binding affinities of these polyamides have been shown to be as strong as those of transcription factors. ${ }^{29}$ Thus, PIPs can inhibit the function of DNA-binding factors, including transcription factors and DNA modification factors, via competitive binding to their recognition sites. ${ }^{26-29}$ In a previous study, Dervan et al. ${ }^{30}$ reported that PIPs recognizing 4-5-bp of CG-rich DNA sequences could inhibit the action of DNMT on plasmids with semiartificial sequences and $\lambda$-phage DNA in vitro. In this study, we demonstrated that a longer PIP recognizing 8-bp (MLH1_-16) can also inhibit DNMT selectively in vitro and in cellulo. Moreover, the CpG site where DNA methylation was inhibited by MLH1_-16 is an endogenous sequence of the $M L H 1$ promoter, and the MLH1_-16-mediated selective inhibition of DNA methylation resulted in the inhibition of $M L H 1$ gene silencing in RKO cells. 
As shown in Figure 4, a simple treatment of MLH1_-16 could not reduce the DNA methylation levels, suggesting that maintenance DNA methylation by DNMT1 could not be inhibited by PIPs in living cells. By contrast, MLH1_-16 inhibited de novo DNA methylation after treatment of AZA (+TSA) followed by culturing under hypoxic conditions (Figure 7), suggesting that de novo DNA methylation by DNMT3 could be inhibited by PIPs in living cells. It is well known that DNMT1 rapidly maintains $\mathrm{CpG}$ methylation on daughter chains immediately after DNA replication. ${ }^{36,37}$ Further studies would be required to clarify the details, such as whether MLH1_-16 could not bind to dsDNA before DNMT1 completes maintenance methylation and thus could not reduce the DNA methylation levels in cellulo. Although the concentrations of MLH1_-16 and MLH1_non were limited up to $5 \mu \mathrm{M}$ because of their solubility, a higher concentration could show better effects. Therefore, we are going to modify the MLH1_-16 structure including changing the recognition size and water solubility.

2.8. Implications for Colorectal Cancer and Other Conditions. The MLH1 gene is a human homolog of the Escherichia coli DNA mismatch repair gene mutL, and mutation of $M L H 1$ and of other mismatch repair genes (e.g., $M S H 3$ and MSH6) is known to cause hereditary nonpolyposis colon cancer (HNPCC). ${ }^{8,9,31,32}$ MLH1 mediates protein-protein interactions during mismatch recognition, strand discrimination, and strand removal. Defects in $M L H 1$ are thus associated with MSI observed in HNPCC. ${ }^{31,32}$ In sporadic colorectal cancer, promoter hypermethylation, rather than mutation, causes inactivation of the MLH1 gene. ${ }^{31,32}$ A subgroup of sporadic colorectal cancers is known to exhibit CIMP, a phenotype characterized by significant hypermethylation of promoter $\mathrm{CpG}$ islands. ${ }^{4,5} \mathrm{CIMP}(+)$ colorectal cancer is known to develop through the serrated pathway of colorectal carcinogenesis. Sessile serrated adenoma is characterized by CIMP, ${ }^{38}$ mutation of $B R A F,{ }^{39,40}$ and preferential occurrence in the right-side colon, but loss of MLH1 protein expression is rarely observed in the early adenoma stage. ${ }^{9}$ The MLH1 promoter is hypermethylated in the late stages of the serrated pathway, leading to loss of MLH1 and thus MSI and hypermutation of genes, causing colorectal cancer. ${ }^{9}$ MLH1 methylation is thus a critical step in the progression of this type of colorectal cancer, and we therefore chose to use the MLH1 promoter region to determine the success of PIP-mediated targeted inhibition of DNA methylation in this study.

It has been reported that methylation of the $M L H 1$ promoter is accelerated in RKO cells by hypoxic stress via a pathway dependent on the histone demethylase LSD $1 .{ }^{33}$ In that report, knockdown of LSD1 or its corepressor CoREST prevented the resilencing of the endogenous $M L H 1$ promoter in RKO cells following transient reactivation by AZA. We therefore investigated whether MLH1_-16 also prevented the resilencing of $M L H 1$ under the same hypoxic conditions and showed that MLH1_-16 inhibits the silencing of $M L H 1$ through inhibition of DNA methylation in a region-specific manner. In addition to this hypoxia model, there are other methylation induction models in the literature, such as the one involving Epstein-Barr viral infection of gastric epithelial cells ${ }^{6,41}$ and the one involving TET inactivation caused by $\mathrm{IDH} 2$ mutation in neural progenitor cells. ${ }^{42}$ Chronic infection of the gastric epithelium by Helicobacter also induces hypermethylation of a subset of genes. ${ }^{41,43-45}$ Although methylation of the MLH1 promoter is not necessarily induced in these models, future studies may involve designing other PIPs to recognize additional hypermethylation target genes, such as $p 16,{ }^{41,46}$ another critical tumor-suppressor gene. Recently, it has been reported that fusion proteins composed of DNA-binding domains and DNA-methylation editing machineries represent potentially useful toolkits for performing targeted editing of epigenomic modifications. ${ }^{47-49}$ However, these protein-based methods require genomic introduction such as a virus infection. On the other hand, PIPs are small molecules that are cellpermeable and intravenously injectable to treat target tissues/ cells. $^{28,50}$ Investigations into the effects of targeted methylation inhibition in these models should be highly informative and may eventually prove clinically useful.

\section{EXPERIMENTAL SECTION}

3.1. Cell Culture and DNA/RNA Extraction. The colorectal cancer cell line RKO was purchased from the American Type Culture Collection (ATCC; Manassas, VA, USA). RKO cells were maintained in Eagle's minimum essential medium containing $10 \%$ heat-inactivated fetal bovine serum (FBS), $100 \mathrm{U} / \mathrm{mL}$ penicillin, and $100 \mu \mathrm{g} / \mathrm{mL}$ streptomycin and were grown in a humidified incubator at $37^{\circ} \mathrm{C}$. Genomic DNA and total RNA from RKO cells were extracted using QIAamp DNA Micro Kit (QIAGEN, Hilden, Germany) and RNAeasy Mini Kit (QIAGEN), respectively.

3.2. Design of PIP-Targeting TSS Region of Human MLH1. MLH1_-16 was designed with the sequence Ac-Py$\operatorname{Im}-\beta$-Im-Im-Py- $\gamma$-Im-Py- $\beta$-Im-Py-Py- $\beta$-Dp, where $\beta$ represents $\beta$-alanine, $\gamma$ represents $\gamma$-aminobutyric acid, and $\mathrm{Dp}$ indicates dimethylaminopropylamide. $\mathrm{MLH} 1_{-}-16$ was designed to recognize the CpG site upstream of the TSS of the human $M L H 1$ gene (positions -19 to -12 , when the TSS is regarded as +1 ). MLH1 non (Ac-Im-Py- $\beta$-Im-Py-Py- $\gamma$-Im-Py-Py- $\beta$-Im$\mathrm{Py}-\beta-\mathrm{Dp})^{26}$ has no binding site in the $M L H 1$ promoter region (Figure 1). These PIPs were purchased from Hipep Laboratories (Kyoto, Japan) and stocked by dissolving the compound in DMSO at $20 \mathrm{mM}$. The working solution was serially diluted to obtain the desired concentration.

3.3. Electrophoretic Mobility Shift Assay (EMSA). The 15-bp dsDNA region containing the 5 ' segment of MLH1 (-22 to -8), with a composition of 5'-FAM-AGTAGCCGCTTCAGG-3' annealed with 5'-CCTGAAGCGGCTACT-3', was used for the EMSA. In a $0.2 \mathrm{~mL}$ tube, $1.0 \mu \mathrm{M}$ FAM-labeled dsDNA was incubated with serially diluted concentrations of MLH1_-16 or MLH1_non in a $10 \mu \mathrm{L}$ reaction solution containing $10 \mathrm{mM}$ Tris- $\overline{\mathrm{H} C l}(\mathrm{pH} 8.0)$ and $10 \%$ DMSO for $1 \mathrm{~h}$ at $37{ }^{\circ} \mathrm{C}$ on a T100 Thermal Cycler (Bio-Rad Laboratories, Hercules, CA, USA). The resultant complexes were loaded onto a $20 \%$ polyacrylamide gel and separated using EMSA in $0.5 \times$ TBE. Selective binding between each PIP and the dsDNA was visualized using an LAS-3000 imaging system (Fujifilm, Tokyo, Japan).

3.4. SPR Assay. All SPR experiments were performed on a ProteON XPR36 system (Bio-Rad) at $25{ }^{\circ} \mathrm{C}$, as described previously. ${ }^{28}$ Biotinylated hairpin 72 -mer nucleotides (5'biotin-TAGCGGGCAG TAGCCGCTTC AGGGAGGGAC GAAGTTTTCT TCGTCCCTCC CTGAAGCGGC TACTGCCCGC TA-3') including MLH1 -16 targeting sequence were immobilized on a streptavidin-coated SA sensor chip at a flow rate of $20 \mu \mathrm{L} / \mathrm{m}$ to obtain the required immobilization level [up to approximately 1000 resonance units (RU)]. The samples were dissolved in HBS-EP buffer [10 mM 4-(2-hydroxyethyl)-1-piperazineethanesulfonic acid (HEPES), 
$150 \mathrm{mM} \mathrm{NaCl}, 3 \mathrm{mM}$ ethylenediamine tetraacetic acid (EDTA), and $0.005 \%$ surfactant P20] with $0.1 \%$ DMSO at $25{ }^{\circ} \mathrm{C}, \mathrm{pH} 7.4$ for the experiment.

3.5. Distribution of FITC-Labeled MLH1_-16 in Cultured RKO Cells. RKO cells were seeded at a density of $1.0 \times 10^{5}$ cells per $35 \mathrm{~mm}$ dish and grown in $2 \mathrm{~mL}$ of a medium. After $24 \mathrm{~h}$, the cells were incubated with $1.0 \mu \mathrm{M}$ FAM-labeled MLH1 - 16 (FAM- $\beta$-Py-Im- $\beta$-Im-Im-Py- $\gamma$-ImPy- $\beta$-Im-Py-Py- $\beta$-Dp) for $24 \mathrm{~h}$ and then fixed with $10 \%$ $\mathrm{HCHO}$ for $2 \mathrm{~h}$ on ice. The fixed cells were washed twice with phosphate-buffered saline (PBS) followed by nuclear staining with $1.0 \mu \mathrm{g} / \mathrm{mL}$ of $4^{\prime}$,6-diamidino-2-phenylindole (DAPI). The cells were visualized using a BZ-X710 fluorescence microscope (Keyence, Osaka, Japan).

3.6. Plasmid Construction. DNA fragments from the $5^{\prime}$ region of $\mathrm{MLH1}$ ( -780 to +483$)$ were amplified using polymerase chain reaction (PCR) from the genomic DNA of RKO cells. Primer sequences are listed in Table S1. PCR products were ligated into pGEM-T Easy vectors (Promega, Fitchburg, WI, USA), according to the manufacturer's instructions. E. coli XLI-Blue competent cells (Agilent Technologies, Santa Clara, CA, USA) were transformed and cultured on Luria-Bertani (LB) plates with $100 \mu \mathrm{g} / \mathrm{mL}$ ampicillin, $32 \mu \mathrm{g} / \mathrm{mL} \mathrm{X-gal,} \mathrm{and} 400 \mu \mathrm{g} / \mathrm{mL}$ isopropyl- $\beta$-Dthiogalactopyranoside overnight at $37{ }^{\circ} \mathrm{C}$. Appropriate colonies were selected by colony-direct PCR using the primers gMLH1_-780F and SP6_R (Table S1) and were transferred to $100 \mathrm{~mL} \mathrm{LB}$ medium with $100 \mu \mathrm{g} / \mathrm{mL}$ ampicillin and cultured overnight at $37{ }^{\circ} \mathrm{C}$. Plasmids with appropriate inserts were extracted using a NucleoBond Xtra Midi column (Macherey Nagel, Bethlehem, PA, USA), and then the concentration of the plasmid was determined using a NanoDrop 2000 spectrophotometer (Thermo Fisher Scientific, Waltham, MA, USA).

3.7. In Vitro Inhibition of CpG Methylation. In a $0.2 \mathrm{~mL}$ tube, $1.0 \mu \mathrm{g}$ unmethylated plasmid DNA including $M L H 1$ $(-780$ to +483$)$ was incubated with serially diluted concentrations of MLH1_-16 or $40 \mu \mathrm{M}$ MLH1_non in 10 $\mu \mathrm{L}$ of $1 \times$ NEB Buffer 2 (New England Biolabs, Ipswich, MA, USA) for $12 \mathrm{~h}$ at $25^{\circ} \mathrm{C}$. A control sample of unmethylated plasmid DNA in buffer with DMSO only was also incubated for $12 \mathrm{~h}$ at $25{ }^{\circ} \mathrm{C}$. After incubation, $S$-adenosyl methionine (New England Biolabs) and CpG methyltransferase M Sss I (New England Biolabs) were added to the samples to a final concentration of $320 \mu \mathrm{M}$ and $0.2 \mathrm{U} / \mu \mathrm{L}$, respectively, resulting in $20 \mu \mathrm{L}$ of total solution (final concentration of the $4.2-\mathrm{kbp}$ plasmid DNA, $18 \mathrm{nM}$ ), to which was added 5\% DMSO. A negative control contained distilled water instead of $\mathrm{CpG}$ methyltransferase. The samples were then incubated for $2 \mathrm{~h}$ at $37^{\circ} \mathrm{C}$ on a T100 thermal cycler followed by heat-inactivation for $20 \mathrm{~min}$ at $65{ }^{\circ} \mathrm{C}$. The DNA was ethanol-precipitated in a centrifuge at $4{ }^{\circ} \mathrm{C}$ for $10 \mathrm{~min}$ with the addition of $2 \mu \mathrm{L}$ of $3 \mathrm{M}$ $\mathrm{NaOAc}$ ( $\mathrm{pH} 5.2$ ) and $50 \mu \mathrm{L}$ of ethanol at $-20{ }^{\circ} \mathrm{C}$. The DNA was washed twice with ice-cold $70 \%$ ethanol and allowed to airdry for $30 \mathrm{~min}$. The DNA was dissolved in $100 \mu \mathrm{L}$ of $10 \mathrm{mM}$ Tris- $\mathrm{HCl}$ buffer ( $\mathrm{pH}$ 8.0) and used for PCR amplification followed by pyrosequencing, as described below.

3.8. AZA/TSA Treatment. RKO cells were seeded at a density of $1 \times 10^{5}$ cells per $6 \mathrm{~cm}$ dish and incubated for $24 \mathrm{~h}$. Next, the cells were exposed to AZA by replacing the medium with a fresh medium containing $5.0 \mu \mathrm{M}$ AZA every $24 \mathrm{~h}$. The cells were also exposed to TSA for $24 \mathrm{~h}$ by replacing the medium containing AZA with a medium containing $100 \mathrm{nM}$ TSA on day 7 . The cells were harvested on day 8 or were collected and subjected to hypoxic conditions, as described below.

3.9. Growth-Inhibiting Effects of PIPs in RKO Cells. RKO cells were plated at 2000 cells/well on 96-well plates with $50 \mu \mathrm{L}$ of a culture medium. One day later, the medium was changed to $100 \mu \mathrm{L}$ of fresh medium containing 1.0, 2.5, 5.0, and $10 \mu \mathrm{M}$ of the compounds. In all experiments, the final DMSO concentration was the same $(0.1 \%)$. After treatment with the compounds for $72 \mathrm{~h}, 10 \mu \mathrm{L}$ of the WST- 8 reagent (Dojindo, Kumamoto, Japan) was added into each well followed by incubation for $2 \mathrm{~h}$ at $37^{\circ} \mathrm{C}$. Absorbance was then measured at $450 \mathrm{~nm}$ using a SpectraMax PLUS 384 microplate reader (Molecular Devices, Sunnyvale, CA, USA).

3.10. Treatment with PIP under Hypoxic Conditions. To culture cells under severe hypoxia at $1 \% \mathrm{O}_{2}$, the cells were maintained under a continuous flow of a humidified mixture of $94 \% \mathrm{~N}_{2}, 5 \% \mathrm{CO}_{2}$, and $1 \% \mathrm{O}_{2}$ in an incubator with an $\mathrm{O}_{2}$ sensor and a MCO-18M regulator (Sanyo, Osaka, Japan). The $\mathrm{CO}_{2}$ level was maintained at $5 \%$ using an internal $\mathrm{CO}_{2}$-regulation system. RKO cells treated with AZA/TSA for 8 days (H0) were subsequently treated with $5.0 \mu \mathrm{M}$ MLH1_-16 or MLH1_non containing $0.1 \%$ DMSO for 30 days. The medium containing PIP was refreshed every 5 days, and the cells were passaged at a density of $2 \times 10^{5}$ cells per $6 \mathrm{~cm}$ dish when the cells became nearly confluent. The cells were harvested on day $0(\mathrm{H} 0$, without hypoxia treatment), day 20 (H20), and day 30 (H30).

3.11. Bisulfite Conversion and Methylation Analysis Using Pyrosequencing. Bisulfite conversion of DNA was performed using the EZ DNA Methylation Kit (Zymo Research, Irvine, CA, USA), and the resultant product was suspended in $40 \mu \mathrm{L}$ of distilled water. The methylation status of the PCR product was quantitatively determined using pyrosequencing, as previously described. ${ }^{6,9}$ Briefly, the biotinylated PCR product was bound to Streptavidin Sepharose High Performance beads (GE Healthcare Life Sciences, Little Chalfont, UK), washed, and denatured using a $0.2 \mathrm{M} \mathrm{NaOH}$ solution. After the addition of $300 \mathrm{nM}$ sequencing primer to the purified single-stranded PCR product, pyrosequencing was carried out on a PyroMark Q24 MD System (Qiagen) with the Pyro Q-CpG software (Qiagen) according to the manufacturer's instructions. Primer sequences and conditions, as well as the number of analyzed CpG sites, are shown in Table S2. Methylation control samples (0 and $100 \%$ methylated $)^{51,52}$ were used for confirmation in every assay.

3.12. Analysis of mRNA Expression Levels by Reverse Transcription (RT)-PCR. First-strand cDNA synthesis was carried out using SuperScript III Reverse Transcriptase and oligo dT primers (Thermo Fisher Scientific), according to the manufacturer's instructions. RT-PCR analyses of $M L H 1$ and GAPDH genes were performed in RKO cells treated with AZA and TSA followed by subsequent treatment by PIP under $1 \%$ $\mathrm{O}_{2}$ conditions. PCR was performed using FastTaq polymerase (Roche, Basel, Switzerland). PCR primers and conditions are shown in Table S1. Each PCR product $(5 \mu \mathrm{L})$ was then separated on a $2 \%$ agarose gel, stained with ethidium bromide, and visualized using a Gel Doc EZ Imager (Bio-Rad Laboratories).

3.13. Statistical Analysis. The differences in the methylation levels were analyzed using the Student's $t$ test. Unless otherwise specified, $P$ values of $<0.05$ were considered to denote statistical significance. All statistical analyses were performed using R software (www.r-project.org/). 


\section{ASSOCIATED CONTENT}

\section{S Supporting Information}

The Supporting Information is available free of charge on the ACS Publications website at DOI: 10.1021/acsomega.6b00229.

Primer sequences for PCR, primer sequences for methylation analysis, distribution of FITC-labeled MLH1 non in RKO cells after 1 day of incubation, dissociation equilibrium constant of $\mathrm{MLH} 1_{-}-16$, growth-inhibiting effects of PIPs in RKO cells, DNA methylation levels at more distant $\mathrm{CpG}$ sites from the PIP-binding site, and selective inhibition of DNA methylation and MLH1 silencing by PIP in RKO cells (PDF)

\section{AUTHOR INFORMATION}

\section{Corresponding Author}

*E-mail: kaneda@chiba-u.jp. Phone: +81-43-226-2039. Fax: +81-43-226-2039 (A.K.).

ORCID

Hiroki Nagase: 0000-0002-3992-5399

Tetsuhiro Nemoto: 0000-0001-8858-161X

Atsushi Kaneda: 0000-0002-6980-5515

\section{Notes}

The authors declare the following competing financial interest(s): As for Inhibition of DNA methylation in living cells, we filed a patent for PIP molecule.

\section{ACKNOWLEDGMENTS}

The authors thank Chihomi Sato for technical assistance and Editage (www.editage.jp) for English language editing. This study was supported in part by Practical Research for Innovative Cancer Control program (A.K.) and AMEDCREST (A.K.) from the Japan Agency for Medical Research and Development, Grants-in-Aid from the Ministry of Education, Culture, Sports, Science, and Technology (26350977 for K.S. and 16K15608 for A.K.), grant from the Takeda Science Foundation (K.S.), grant from the Tokyo Biochemical Research Foundation (K.S.), and grant from the Global and Prominent Research, Chiba University (A.K.).

\section{REFERENCES}

(1) Bird, A. P. CpG-rich islands and the function of DNA methylation. Nature 1986, 321, 209-213.

(2) Jones, P. A.; Baylin, S. B. The epigenomics of cancer. Cell 2007, $128,683-692$.

(3) Rountree, M. R.; Bachman, K. E.; Herman, J. G.; Baylin, S. B. DNA methylation, chromatin inheritance, and cancer. Oncogene 2001, 20, 3156-3165.

(4) Toyota, M.; Ahuja, N.; Ohe-Toyota, M.; Herman, J. G.; Baylin, S. B.; Issa, J.-P. J. CpG island methylator phenotype in colorectal cancer. Proc. Natl. Acad. Sci. U.S.A. 1999, 96, 8681-8686.

(5) Issa, J.-P. CpG island methylator phenotype in cancer. Nat. Rev. Cancer 2004, 4, 988-993.

(6) Matsusaka, K.; Kaneda, A.; Nagae, G.; Ushiku, T.; Kikuchi, Y.; Hino, R.; Uozaki, H.; Seto, Y.; Takada, K.; Aburatani, H.; Fukayama, M. Classification of Epstein-Barr virus-positive gastric cancers by definition of DNA methylation epigenotypes. Cancer Res. 2011, 71, $7187-7197$

(7) Herman, J. G.; Umar, A.; Polyak, K.; Graff, J. R.; Ahuja, N.; Issa, J.-P. J.; Markowitz, S.; Willson, J. K. V.; Hamilton, S. R.; Kinzler, K. W.; Kane, M. F.; Kolodner, R. D.; Vogelstein, B.; Kunkel, T. A.; Baylin, $\mathrm{S}$. B. Incidence and functional consequences of hMLH1 promoter hypermethylation in colorectal carcinoma. Proc. Natl. Acad. Sci. U.S.A. 1998, 95, 6870-6875.

(8) The Cancer Genome Atlas Network. Comprehensive molecular characterization of human colon and rectal cancer. Nature 2012, 487, 330-337.

(9) Sakai, E.; Fukuyo, M.; Ohata, K.; Matsusaka, K.; Doi, N.; Mano, Y.; Takane, K.; Abe, H.; Yagi, K.; Matsuhashi, N.; Fukushima, J.; Fukayama, M.; Akagi, K.; Aburatani, H.; Nakajima, A.; Kaneda, A. Genetic and epigenetic aberrations occurring in colorectal tumors associated with serrated pathway. Int. J. Cancer 2016, 138, 1634-1644.

(10) Jones, P. A.; Taylor, S. M. Cellular differentiation, cytidine analogs and DNA methylation. Cell 1980, 20, 85-93.

(11) Issa, J.-P. J.; Kantariian, H. M.; Kirkpatrick, P. Azacitidine. Nat. Rev. Drug Discovery 2005, 4, 275-276.

(12) Christman, J. K. 5-Azacytidine and 5-aza-2'-deoxycytidine as inhibitors of DNA methylation: Mechanistic studies and their implications for cancer therapy. Oncogene 2002, 21, 5483-5495.

(13) Estey, E. H. Epigenetics in clinical practice: The examples of azacitidine and decitabine in myelodysplasia and acute myeloid leukemia. Leukemia 2013, 27, 1803-1812.

(14) de Vos, D. Epigenetic drugs: A longstanding story. Semin. Oncol. 2005, 32, 437-442.

(15) Quintás-Cardama, A.; Santos, F. P. S.; Garcia-Manero, G. Therapy with azanucleosides for myelodysplastic syndromes. Nat. Rev. Clin. Oncol. 2010, 7, 433-444.

(16) Waring, M. J.; Wakelin, L. P. G. Echinomycin: A bifunctional intercalating antibiotic. Nature 1974, 252, 653-657.

(17) Trauger, J. W.; Baird, E. E.; Mrksich, M.; Dervan, P. B. Extension of sequence-specific recognition in the minor groove of DNA by pyrrole-imidazole polyamides to $9-13$ base pairs. J. Am. Chem. Soc. 1996, 118, 6160-6166.

(18) White, S.; Szewczyk, J. W.; Turner, J. M.; Baird, E. E.; Dervan, P. B. Recognition of the four Watson-Crick base pairs in the DNA minor groove by synthetic ligands. Nature 1998, 391, 468-471.

(19) Kielkopf, C. L.; Baird, E. E.; Dervan, P. B.; Rees, D. C. Structural basis for G.C recognition in the DNA minor groove. Nat. Struct. Biol. 1998, 5, 104-109.

(20) Dervan, P. B.; Edelson, B. S. Recognition of the DNA minor groove by pyrrole-imidazole polyamides. Curr. Opin. Struct. Biol. 2003, 13, 284-299.

(21) Murty, M. S. R. C.; Sugiyama, H. Biology of $N$-methylpyrrole- $N$ methylimidazole hairpin polyamide. Biol. Pharm. Bull. 2004, 27, 468474.

(22) Swalley, S. E.; Baird, E. E.; Dervan, P. B. A pyrrole-imidazole polyamide motif for recognition of eleven base pair sequences in the minor groove of DNA. Chem.-Eur. J. 1997, 3, 1600-1607.

(23) Trauger, J. W.; Baird, E. E.; Dervan, P. B. Recognition of 16 base pairs in the minor groove of DNA by a pyrrole-imidazole polyamide dimer. J. Am. Chem. Soc. 1998, 120, 3534-3535.

(24) Turner, J. M.; Swalley, S. E.; Baird, E. E.; Dervan, P. B. Aliphatic/aromatic amino acid pairings for polyamide recognition in the minor groove of DNA. J. Am. Chem. Soc. 1998, 120, 6219-6226.

(25) Wang, C. C. C.; Ellervik, U.; Dervan, P. B. Expanding the recognition of the minor groove of DNA by incorporation of $\beta$-alanine in hairpin polyamides. Bioorg. Med. Chem. 2001, 9, 653-657.

(26) Wang, X.; Nagase, H.; Watanabe, T.; Nobusue, H.; Suzuki, T.; Asami, Y.; Shinojima, Y.; Kawashima, H.; Takagi, K.; Mishra, R.; Igarashi, J.; Kimura, M.; Takayama, T.; Fukuda, N.; Sugiyama, H. Inhibition of MMP-9 transcription and suppression of tumor metastasis by pyrrole-imidazole polyamide. Cancer Sci. 2010, 101, $759-766$.

(27) Suzuki, T.; Asami, Y.; Takahashi, T.; Wang, X.; Watanabe, T.; Bando, T.; Sugiyama, H.; Fukuda, N.; Nagase, H. Development of a molecule-recognized promoter DNA sequence for inhibition of HER2 expression. J. Antibiot. 2009, 62, 339-341.

(28) Matsuda, H.; Fukuda, N.; Ueno, T.; Tahira, Y.; Ayame, H.; Zhang, W.; Bando, T.; Sugiyama, H.; Saito, S.; Matsumoto, K.; Mugishima, H.; Serie, K. Development of gene silencing pyrrole- 
imidazole polyamide targeting the TGF- $\beta 1$ promoter for treatment of progressive renal diseases. J. Am. Soc. Nephrol. 2006, 17, 422-432.

(29) Dervan, P. B.; Doss, R. M.; Marques, M. A. Programmable DNA binding oligomers for control of transcription. Curr. Med. Chem.: AntiCancer Agents 2005, 5, 373-387.

(30) Kang, J. S.; Meier, J. L.; Dervan, P. B. Design of sequencespecific DNA binding molecules for DNA methyltransferase inhibition. J. Am. Chem. Soc. 2014, 136, 3687-3694.

(31) Hawkins, N.; Norrie, M.; Cheong, K.; Mokany, E.; Ku, S.-L.; Meagher, A.; O'Connor, T.; Ward, R. CpG island methylation in sporadic colorectal cancers and its relationship to microsatellite instability. Gastroenterology 2002, 122, 1376-1387.

(32) Kane, M. F.; Loda, M.; Gaida, G. M.; Lipman, J.; Mishra, R.; Goldman, H.; Jessup, J. M.; Kolodner, R. Methylation of the hMLH1 promoter correlates with lack of expression of hMLH1 in sporadic colon tumors and mismatch repair-defective human tumor cell lines. Cancer Res. 1997, 57, 808-811.

(33) Lu, Y.; Wajapeyee, N.; Turker, M. S.; Glazer, P. M. Silencing of the DNA mismatch repair gene MLH1 induced by hypoxic stress in a pathway dependent on the histone demethylase LSD1. Cell Rep. 2014, $8,501-513$.

(34) Suzuki, H.; Gabrielson, E.; Chen, W.; Anbazhagan, R; van Engeland, M.; Weijenberg, M. P.; Herman, J. G.; Baylin, S. B. A genomic screen for genes upregulated by demethylation and histone deacetylase inhibition in human colorectal cancer. Nat. Genet. 2002, $31,141-149$.

(35) Gius, D.; Cui, H.; Bradbury, C. M.; Cook, J.; Smart, D. K.; Zhao, S.; Young, L.; Brandenburg, S. A.; Hu, Y.; Bisht, K. S.; Ho, A. S.; Mattson, D.; Sun, L.; Munson, P. J.; Chuang, E. Y.; Mitchell, J. B.; Feinberg, A. P. Distinct effects on gene expression of chemical and genetic manipulation of the cancer epigenome revealed by a multimodality approach. Cancer Cell 2004, 6, 361-371.

(36) Svedruzic, Z. M. Mammalian cytosine DNA methyltransferase Dnmt1: Enzymatic mechanism, novel mechanism-based inhibitors, and RNA-directed DNA methylation. Curr. Med. Chem. 2008, 15, 92106.

(37) Wood, R. J.; McKelvie, J. C.; Maynard-Smith, M. D.; Roach, P. L. A real-time assay for CpG-specific cytosine-C5 methyltransferase activity. Nucleic Acids Res. 2010, 38, No. e107.

(38) Vogelstein, B.; Fearon, E. R.; Hamilton, S. R.; Kern, S. E.; Preisinger, A. C.; Leppert, M.; Smits, A. M. M.; Bos, J. L. Genetic alterations during colorectal-tumor development. N. Engl. J. Med. 1988, 319, 525-532.

(39) Ushijima, T. Detection and interpretation of altered methylation patterns in cancer cells. Nat. Rev. Cancer 2005, 5, 223-231.

(40) Weisenberger, D. J.; Siegmund, K. D.; Campan, M.; Young, J.; Long, T. I.; Faasse, M. A.; Kang, G. H.; Widschwendter, M.; Weener, D.; Buchanan, D.; Koh, H.; Simms, L.; Barker, M.; Leggett, B.; Levine, J.; Kim, M.; French, A. J.; Thibodeau, S. N.; Jass, J.; Haile, R.; Laird, P. W. CpG island methylator phenotype underlies sporadic microsatellite instability and is tightly associated with BRAF mutation in colorectal cancer. Nat. Genet. 2006, 38, 787-793.

(41) Matsusaka, K.; Funata, S.; Fukayama, M.; Kaneda, A. DNA methylation in gastric cancer, related to Helicobacter pylori and Epstein-Barr virus. World J. Gastroenterol. 2014, 20, 3916-3926.

(42) Lu, C.; Ward, P. S.; Kapoor, G. S.; Rohle, D.; Turcan, S.; AbdelWahab, O.; Edwards, C. R.; Khanin, R.; Figueroa, M. E.; Melnick, A.; Wellen, K. E.; O’Rourke, D. M.; Berger, S. L.; Chan, T. A.; Levine, R. L.; Mellinghoff, I. K.; Thompson, C. B. IDH mutation impairs histone demethylation and results in a block to cell differentiation. Nature 2012, 483, 474-478.

(43) Sepulveda, A. R.; Yao, Y.; Yan, W.; Park, D., II; Kim, J. J.; Gooding, W.; Abudayyeh, S.; Graham, D. Y. CpG methylation and reduced expression of $\mathrm{O}^{6}$-methylguanine DNA methyltransferase is associated with Helicobacter pylori infection. Gastroenterology 2010, $138,1836-1844$.

(44) Tahara, T.; Arisawa, T.; Shibata, T.; Nakamura, M.; Yoshioka, D.; Okubo, M.; Maruyama, N.; Kamano, T.; Kamiya, Y.; Fujita, H.; Nakagawa, Y.; Nagasaka, M.; Iwata, M.; Takahama, K.; Watanabe, M.;
Yamashita, H.; Hirata, I. Increased number of methylated CpG islands correlates with Helicobacter pylori infection, histological and serological severity of chronic gastritis. Eur. J. Gastroenterol. Hepatol. 2009, 21, 613-619.

(45) Liu, Y.-C.; Shen, C.-Y.; Wu, H.-S.; Chan, D.-C.; Chen, C.-J.; Yu, J.-C.; Yu, C.-P.; Harn, H.-J.; Shyu, R.-Y.; Shih, Y.-L.; Hsieh, C.-B.; Hsu, H.-M. Helicobacter pylori infection in relation to E-cadherin gene promoter polymorphism and hypermethylation in sporadic gastric carcinomas. World J. Gastroenterol. 2005, 11, 5174-5179.

(46) Merlo, A.; Herman, J. G.; Mao, L.; Lee, D. J.; Gabrielson, E.; Burger, P. C.; Baylin, S. B.; Sidransky, D. 5' CpG island methylation is associated with transcriptional silencing of the tumour suppressor p16/CDKN2/MTS1 in human cancers. Nat. Med. 1995, 1, 686-692.

(47) Maeder, M. L.; Angstman, J. F.; Richardson, M. E.; Linder, S. J.; Cascio, V. M.; Tsai, S. Q.; Ho, Q. H.; Sander, J. D.; Reyon, D.; Bernstein, B. E.; Costello, J. F.; Wilkinson, M. F.; Joung, J. K. Targeted DNA demethylation and activation of endogenous genes using programmable TALE-TET1 fusion proteins. Nat. Biotechnol. 2013, $31,1137-1142$.

(48) Liu, X. S.; Wu, H.; Ji, X.; Stelzer, Y.; Wu, X.; Czauderna, S.; Shu, J.; Dadon, D.; Young, R. A.; Jaenisch, R. Editing DNA Methylation in the Mammalian Genome. Cell 2016, 167, 233-247.

(49) Morita, S.; Noguchi, H.; Horii, T.; Nakabayashi, K.; Kimura, M.; Okamura, K.; Sakai, A.; Nakashima, H.; Hata, K.; Nakashima, K.; Hatada, I. Targeted DNA demethylation in vivo using dCas9-peptide repeat and scFv-TET1 catalytic domain fusions. Nat. Biotechnol. 2016, 34, 1060-1065.

(50) Hiraoka, K.; Inoue, T.; Taylor, R. D.; Watanabe, T.; Koshikawa, N.; Yoda, H.; Shinohara, K.-i.; Takatori, A.; Sugimoto, H.; Maru, Y.; Denda, T.; Fujiwara, K.; Balmain, A.; Ozaki, T.; Bando, T.; Sugiyama, H.; Nagase, H. Inhibition of KRAS codon 12 mutants using a novel DNA-alkylating pyrrole-imidazole polyamide conjugate. Nat. Commun. 2015, 6, 6706.

(51) Yagi, K.; Akagi, K.; Hayashi, H.; Nagae, G.; Tsuji, S.; Isagawa, T.; Midorikawa, Y.; Nishimura, Y.; Sakamoto, H.; Seto, Y.; Aburatani, H.; Kaneda, A. Three DNA methylation epigenotypes in human colorectal cancer. Clin. Cancer Res. 2010, 16, 21-33.

(52) Kaneda, A.; Yagi, K. Quantitative DNA methylation analysis for epigenotyping of colorectal cancer. Methods Mol. Biol. 2015, 1238, 289-299. 